\title{
On new compounds of ammonia with ferrocyanide and ferridcyanide of nickel
}

\section{M.A. Reynoso}

To cite this article: M.A. Reynoso (1850) On new compounds of ammonia with ferrocyanide and ferridcyanide of nickel, Philosophical Magazine Series 3, 36:244, 406-407, DOI:

10.1080/14786445008646511

To link to this article: http://dx.doi.org/10.1080/14786445008646511

Published online: 30 Apr 2009.

Submit your article to this journal $₫$

Џ Article views: 2

Q View related articles ¿ 
the phænomena, so that very variable mixtures of common salt, sulphate of magnesia, and chloride of magnesium are obtained.

The results of evaporation are still more variable above $35^{\circ}$. The mixtures of the salts deposited undergo numerous differences in their composition, without the possibility of foretelling the result of the precipitations : some contain from 0.5 to 0.17 of their weight of potash ; it sometimes happens that this substance is found in deposits formed in solutions, the density of which is only from $34^{\circ}$ to $35^{\circ}$; these deposits are derived from variations in the composition of the waters.-L'Institut, Fevrier 27, 1850.

\section{ON NEW COMPOUNDS OF AMMONIA WITH FERROCYANIDE AND FERRIDCYANIUE OF NICKEL. BY M. A. REYNOSO.}

When excess of ammonia is added to recently precipitated and moist ferrocyanide of nickel, it dissolves at first, changes its colour, and soon produces a precipitate composed of a multitude of very fine needles of a violet colour; these are the ammoniacal ferrocyanide of nickel. It may also be prepared by adding ferrocyanide of potassium to a solution of nickel containing much ammonia, or by causing a solution of the salt of nickel to act upon a mixture of ammonia and ferrocyanide of potassium. In every case the crystals of the salt are finer as they are more slowly formed; that is to say, when there is much ammonia, and the solution is consequently very dilute. The analysis of this salt indicated its formula to be $2 \mathrm{Ni} \mathrm{Cy}, \mathrm{Fe} \mathrm{Cy}, 5 \mathrm{NH}^{3}$, $4 \mathrm{HO}$.

When ferrocyanide of potassium is poured into a solution of ammoniacal nitrate of nickel, a greenish-white precipitate is obtained, which after being well dried is a mass of a very deep green colour, which becomes white by pulverization. It adheres to the tongue, is insipid, and completely insoluble in.water. Ammonia dissolves it and converts it into quinto-ammoniacal ferrocyanide. Heat decomposes it, evolving ammonia and ferrocyanide of ammonia, leaving a carburet which fuses in burning.

This salt is the biammoniacal ferrocyanide of nickel; its formula is $2 \mathrm{Ni} \mathrm{Cy}, \mathrm{Fe} \mathrm{Cy}, 2 \mathrm{NH}^{3}, \mathrm{HO}$.

The ferridcyanide of potassium, poured into ammoniacal nitrate of nickel, produces a fine yellow precipitate, soluble in excess of am. monia. It is the biammoniacal ferridcyanide of nickel, the formula of which is $3 \mathrm{NiCy}, \mathrm{Fe}^{2} \mathrm{Cy}^{3}, 2 \mathrm{NH}^{3}, \mathrm{HO}$.

All the ferrocyanides and ferrideyanides of the metals whose oxides are soluble in ammonia are themselves soluble in ammonia. The alkaline solution of ferridcyanide of cobalt is of a very deep red colour. The ferrocyanides and ferridcyanides of the metals whose oxides are soluble in potash, are themselves soluble in potash. Thus potash added to ferrocyanide of zinc produces immediately ferrocyanide of potassium and oxide of zinc, which dissolves in the excess of potash. If the potash be added with precaution, on filtering, the liquor contains merely ferrocyanide of potassium, and oxide of zinc remains on the filter. With ferrocyanide of mercury the reac- 
tion is very distinct. This compound is white; on treating it with potash, there are produced ferrocyanide of potassium and yellow oxide of mercury, insoluble in excess of potash.-L'Institut, Avril 10, $1850^{\circ}$.

\section{EQUIVALENT OF CHROMIUM. BY M. LEFORT.}

According to Berzelius, the equivalent of chromium is 351 ; other chemists make it 320 and 330 : according to $\mathrm{M}$. Lefort, the equiva. lent is 333 . - Ibid.

\section{METEOROLOGICAL OBSERVATIONS FOR MARCH 1850.}

Chiswick.-March 1. Hazy : very fine: overcast. 2. Densely overcast. 3. Cloudy. 4. Cloudy : clear and frosty at night. 5. Frosty: fine : cloudy. 6, 7. Foggy : fine: clear. 8. Hazy. 9. Slight fog : fine : clear. 10. Very fine. 11. Clear and fine: frosty. 12. Frosty : very fine: clear. 13. Frosty, with slight fog : very fine. 14. Overcast. 15. Overcast : clear, with sharp frost at night. 16. Frosty : overcast : clear. 17. Frosty: cloudy: sunshine occasionally : clear and frosty. 18. Frosty and fine. 19, 20. Cloudy. 21. Cloudy and cold : clear and frosty. 22. Hoar-frost : cloudy. 23. Heavy clouds : sleet-showers. 24. Slight fall of snow-flakes : severe frost at night. 25. Clear and frosty : cloudy : clear : frosty. 26. Overcast. 27. Foggy : slight haze : frosty. 28. Slight laze : bright sun with dry cold air : clear and frosty. 29. Foggy : cloudy : clear. $30,31$. Overcast.

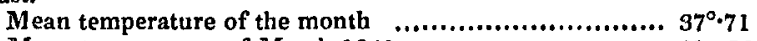

Mean temperature of March 1849 ......................... 41 56

Mean temperature of March for the last twenty-three years $42 \cdot 81$

Average amount of rain in March ............................. 1.36 inch.

Boston. - March 1, 2. Cloudy. 3. Fine: rain P.m. 4. Cloudy. 5-7. Fine. 8, 9. Clondy. 10. Fine. 11. Cloudy. 12, 13. Fine. 14, 15. Cloudy. 16. Cloudy : rain A.ss. 17, 18. Fine. 19. Cloudy : rain A.s. 20. Cloudy. 21. Fine. 22. Cloudy. 23. Fine: rain early A.M. 24. Cloudy: snow A.M. and B. M. 25. Cloudy, 26, 27. Fine. 28. Fine: rain A.M. 29, 30. Fine. 31. Cloudy : rain $A . M$.

Applegarth Manse, Dumfries-shire.-March 1. Fine: a shower early A.M. 2. Slight shower during night : thick P.M. 3. Rain heavy A.M. : cleared. 4. Frost : clear and fine. 5. Moist all day. 6. Mild and growing: moist. 7. Fine spring day. 8. Still finer: clear and warm. 9. Dull and moist : slight shower. 10. Clear and fine: slight shower. 11. Frost : clear and bright. 12. Frost : cloudy. 13. Frost, not so severe. 14, 15. Mild : cluudy : no frost. 16. East wind : dull. 17. Dull : raw : cold : shower. 18. Dull and cloudy, but mild. 19. Dull A. x.: cleared : rain P.M. 20. Very fine : slight drizzle. 21. Fine, though raw A.M. 22. Dry, but cloudy : stormy P.M. 23. Frost : snow: wind. 24. Hard frost : snow : calm P.m. 25. Frost very hard : thermometer $21 \frac{1}{2}^{\circ}$. 26. Frost slight : heavy snow A.M. 27. Frost severe : snow again. 28. Frost still harder : clear. 29. Frost still. 30. Frost moderate : hail : rain P.M. 31. Rain : cloudy and foggy P.M.

Mean temperature of the month $40^{\circ} \cdot 3$

Mean temperature of March 1849 ........................... $41 \cdot 8$

Mean temperature of March for the last twenty-eight years. $39 \cdot 6$

Average rain in March for twenty -three years ............... 2.35 inches.

Sandwick Manse, Orkney.-March 1. Showers : drops. 2. Drizzle. 3. Cloudy : showers. 4. Snow : cloudy. 5. Damp : rain. 6. Drizzle : cloudy. 7. Damp. 8. Fine : drizzle. 9. Cloudy : showers. 10. Sleet : aurora. 11. Bright: clear: aurora. 12. Drizzle. 13. Damp : drizzle. 14. Drizzle: damp. 15. Bright : damp. 16. Cloudy, 17. Drops : showers. 18. Hazy : cloudy. 19. Cloudy. 20. Bright: drops. 2l. Cloudy : drops, 22. Showers: snow-showers. 29. Hail-showers: snow-showers. 24. Snow-drift: snow-show'ers. 25. Snowshowers : large halo. 26. Snow-showers. 27, 28. Bright: snow-showers, 29. Bright : clear. 30. Cloudy. 31. Drops : cloudy. 